\title{
Drought tolerance of Hakea species (Proteaceae) from a range of biomes and life-histories predicted by climatic niche.
}

\author{
Osazee O. Oyanoghafo ${ }^{1,2} *$, Corey O’ Brien $^{1}$, Brendan Choat ${ }^{1}$, David Tissue ${ }^{1}$, Paul D. \\ Rymer $^{1}$ \\ ${ }^{1}$ Hawkesbury Institute for the Environment, Western Sydney University, Richmond, New South Wales 2751, \\ Australia. \\ ${ }^{2}$ Department of Plant Biology and Biotechnology, Faculty of Life Sciences, University of Benin, Benin City, \\ Nigeria. \\ Email: o.oyanoghafo@westernsydney.edu.au; corey_obrien@outlook.com; $\underline{\text { B.Choat@westernsydney.edu.au; }}$ \\ D.Tissue@westernsydney.edu.au; P.Rymer@westernsydney.edu.au \\ *Correspondence: Osazee O. Oyanoghafo; o.oyanoghafo@westernsydney.edu.au
}

Funding: NSW Department for Planning, Industry and Environment, Saving Our Species grant to P.D.R and D.T. Australian Postgraduate Award (Western Sydney University), and Ecological Society of Australia - Holsworth Wildlife Research Endowment grant to O.O.O.

\begin{abstract}
Extreme drought conditions across the globe are impacting biodiversity with serious implications for the persistence of native species. However, quantitative data on drought tolerance is not available for diverse flora to inform conservation management. We quantified physiological drought tolerance in the diverse Hakea genus (Proteaceae) to test predictions based on climaticorigin, life history and functional traits. We sampled terminal branches of replicate plants of 16 species in a common garden. Xylem cavitation was induced in branches under varying water potential (tension) in a centrifuge and the tension generating 50\% loss of conductivity (stem P50)
\end{abstract}


was characterized as a metric for drought tolerance. The same branches were used to estimate plant functional traits, including wood density, specific leaf area, and Huber value (sap flow area to leaf area ratio). There was significant variation in stem P50 among species, which was negatively associated with the species climate-origin (rainfall and aridity). Drought tolerance did not differ among life histories; however, a drought avoidance strategy with terete leaf form and greater Huber value may be important for species to colonize and persist in the arid biome. Our findings will contribute to future prediction of species vulnerability to drought and adaptive management under climate change.

Keywords: Aridity, climate change, drought tolerance, life-history, functional traits, Proteaceae.

Acknowledgement: We appreciate the support of Benedict Lyte from The Royal Botanic Garden, Sydney for granting us excess to their living collections. Nzie Peter for support in data collection and Rosana Lopez for technical insights into the hydraulic techniques. Australian Postgraduate Award (Western Sydney University), Ecological Society of Australia-Holsworth Wildlife Research Endowment grant to O.O.O. This project has been supported by the New South Wales Government's Department for Planning, Industry and Environment, Saving Our Species grant to P.D.R and D.T. 


\section{Introduction}

The impacts of drought on diverse biomes across the globe are substantial, with prolonged drought resulting in forest dieback and plant mortality, changes in species distribution, local extinction and decline in ecosystem function and resilience (Allen et al., 2010; Goulden and Bales, 2019; Powers et al., 2020). Predicting the impacts of drought on biomes and plant lineages remains a challenging task for scientists, as most predictions relying on species distribution models (SDM) and climatic niche data lack the species physiological tolerance (Fitzpatrick et al., 2008; McDowell et al., 2008; Razgour et al., 2019; Urban, 2015). Hence, quantifying species physiological thresholds is key to understanding how plants will cope with extreme climaticinduced events such as drought in the future (Allen et al., 2010).

One promising strategy to quantify physiological tolerance to drought is by characterizing hydraulic traits in relation to water limitation (Choat et al., 2012; Martin-StPaul et al., 2017). This is particularly important, as studies have shown that most flowering plants (angiosperms) function close to their hydraulic safety margin (minimum xylem pressure experienced in the field - water potential causing $50 \%$ loss of conductivity $\left(\mathrm{P}_{50}\right)$ ), and are vulnerable to climate change (Choat et al., 2012). Under prolonged drought conditions, stomatal closure is unable to prevent the continuous decline of the xylem pressure, leading to cavitation, a phase change from liquid water to gas, and the formation of gas emboli (Choat et al., 2012). This results in loss of xylem hydraulic conductivity, and in severe cases, hydraulic failure and subsequent mortality (Anderegg et al., 2016; Brodribb and Cochard, 2009; Cochard, 2014; McDowell et al., 2008; Pockman et al., 1995; Urli et al., 2013). A large body of evidence has shown species drought tolerance is quantitatively linked with resistance to cavitation in woody species (Adams et al., 
2017; Brodribb and Cochard, 2009; Choat et al., 2012; Kursar et al., 2009; McDowell et al., 2008; Pockman et al., 1995). The xylem tensions associated with irreversible damage (hydraulic failure) are approximated by $\mathrm{P}_{50}$ in gymnosperms and by $\mathrm{P}_{88}$ (i.e. water potential at $88 \%$ loss of conductivity) in angiosperms (Anderegg et al., 2016; Urli et al., 2013), possibly reflecting structural and functional differences in water transport systems (Choat et al. 2018).

Plants have adapted to water deficit through a wide range of life history and functional traits, with underlying anatomical and physiological mechanisms enabling them to colonise and persist in variable climate. $\mathrm{P}_{50}$ is known to be correlated with life history (Pratt et al., 2007), structure and function (Brodribb and Holbrook, 2004; Jacobsen et al., 2007), and species climate range (Bourne et al., 2017). For instance, in drier climates species tend to have higher wood density, which provides greater resistance to xylem conduit implosion under high xylem tensions and is strongly correlated with $\mathrm{P}_{50}$ (Barotto et al., 2018; Hacke et al., 2001; Jacobsen et al., 2005). Huber value (HV: ratio of sapwood area to leaf area) is observed to be negatively related to site water availability and $\mathrm{P}_{50}$, such that species in drier climates have higher $\mathrm{HV}$ and more negative $\mathrm{P}_{50}$ than species in wetter climates (Gotsch et al., 2010; Markesteijn et al., 2011). Leaf size has been observed to be negatively related to drought tolerance $\left(\mathrm{P}_{50}\right)$ such that species with small leaves tend to be more cavitation resistant (Markesteijn et al., 2011; Schreiber et al., 2016). Studies have quantified and explored species vulnerability to climate-induced drought $\left(\mathrm{P}_{50}\right)$ in relation to functional traits across biomes (Blackman et al., 2017, 2014; Bourne et al., 2017; Larter et al., 2017; Li et al., 2019, 2018; Lucani et al., 2019; Martorell et al., 2014; Nardini and Luglio, 2014; Pita et al., 2003). However, our knowledge on the drought tolerance $\left(\mathrm{P}_{50}\right)$ of 
diverse related species in relation to the interactive effects of functional and life-history traits on species survival across biomes remain limited.

The Hakea genus is an ideal candidate for exploring variation in physiological drought tolerance across contrasting biomes. This is because Hakea is one of the two genera (the other being Grevillea) within the ancient Gondwana plant family Proteaceae, that have successfully transitioned into the arid biome in the Australian continent. Hakea also display a wide variation in functional and life history traits within and among biomes. For instance, some species resprout either from root suckers, epicormic or lignotuber buds after disturbance such as fire and drought (e.g. H. purpurea, H. drupacea and H. bakeriana), while other Hakea species must rely on seed production (e.g. H. sericea) (Clarke et al., 2013; Groom and Lamont, 1996; Weston, 1995). Leaf morphology varies greatly among species, with broad-leaved (e.g. H. dactyloides, $H$. cristata, H. bucculenta) and terete leaved species (e.g. H. leucoptera, H. tephrospermum, H. sericea) (Groom and Lamont, 1996). The differences in functional traits and life history forms among the genus could influence species response to stress conditions (Groom and Lamont, 1996; Zeppel et al., 2015). Studies have shown that resprouting species tend to allocate more biomass to roots than shoots (Moreira et al., 2012; Pausas et al., 2016), as well as exhibiting lower rates of photosynthesis, hydraulic conductivity, and transpiration (Hernández et al., 2011; Vilagrosa et al., 2014). Leaf shape influences species exposure to drought, as such within warmer and drier sites, species tend to be needle-leaved (Groom and Lamont, 1996; Wright et al., 2017). Resprouting capacity and needle-leaves support a drought avoidance strategy, and as such may have variable drought tolerance (Groom and Lamont, 1996; Vilagrosa et al., 2014; Zeppel et al., 2015). 
In this study we aimed to determine the drought tolerance of Hakea species that differ in life history and climatic niches to investigate what attributes are predictive of aridity. Firstly, we hypothesized that there will be significant variation in drought tolerance between species, and that this would be predicted by different life-histories. Specifically, non-resprouting species will have higher $\mathrm{P}_{50}$ than resprouting species, and that needle-leaved species will have higher $\mathrm{P}_{50}$ than broad-leaved species (Groom and Lamont, 1996; Hernández et al., 2011; Vilagrosa et al., 2014). Secondly, we hypothesized that drought tolerance $\left(\mathrm{P}_{50}\right)$ will be predicted by species climate such that species in drier climates will have higher $\mathrm{P}_{50}$ than species in wetter climates (Bourne et al., 2017; Larter et al., 2017; Trueba et al., 2017). Thirdly, drought tolerance $\left(\mathrm{P}_{50}\right)$ will be positively correlated to Huber Value (HV) and wood density (WD), and negatively correlated to specific leaf area (SLA). This study will therefore provide empirical evidence on species drought tolerance $\left(\mathrm{P}_{50}\right)$ to inform conservation management of diverse native flora.

\section{Materials and Methods}

\section{Experimental design and Species selection}

All samples were collected from the same site, the Australian Botanic Garden (ABG), Mount Annan, NSW, Australia (GPS location: Lat. -34.0703, Log. 150.7668, average annual rainfall of $759 \mathrm{~mm}$ (2007-2016)) and were well-watered via irrigation systems (simulating a common garden design). Comparing multiple species from the same Hakea genus in a common garden minimizes environmental effects and allows quantification of genetically determined trait variation. Using this approach, we examined the variation in functional and hydraulic traits of a diverse array of species sampled from across the Hakea phylogeny (Cardillo et al. 2017). A total of 16 species were selected to represent a wide range of vegetation type, biome, climate, and life 
histories (Table 1). Species occurrence records were downloaded from the Australian Living Atlas (ALA) (https://www.ala.org.au/, 2019). Vegetation type was defined according to the World Wildlife Fund (WWF) as abbreviated by Cardillo et al. (2017); Arid (Deserts and Xeric Shrublands), Mediterranean (Mediterranean Forests, Woodlands and Scrub), Forest (Temperate Broadleaf and Mixed Forests), Grasslands (Temperate Grasslands, Savannas, and Shrublands). The vegetation harboring greater than $50 \%$ of the species occurrence records was assigned as its vegetation type. Biome was defined based on the aridity index (UNEP, 1997) as broadly humid and arid (aridity index $>0.5,<0.5$, respectively). The climate summary details for each species distribution was obtained from The Atlas of Living Australia using R v3.6.3 (RCoreTeam, 2020).

\section{Sampling of Plant material}

Three individuals for each species were sampled from the AGB. Terminal full sunlight, northfacing branch that were $c a .90 \mathrm{~cm}$ long were sampled and placed into a black plastic bag with wet tissue paper and transported immediately to the laboratory ( $<90$ minutes). Samples were stored in a cold room at $4^{\circ} \mathrm{C}$ until they were processed (within 10 days). A standardized $50 \mathrm{~cm}$ branch was cut under water from the terminal end of the collected samples, from which the bottom $10 \mathrm{~cm}$ was excised, barked removed to estimate the sap flow area and then oven dried to obtain the wood density (WD: oven dry mass/volume). All leaves were removed from the remaining $40 \mathrm{~cm}$ branch and leaf area measured using the Li Cor 3100 leaf area meter. Leaf material was oven dried at $70 \mathrm{C}$ for $48 \mathrm{~h}$ prior to obtaining the dry mass. Specific leaf area $\left(\mathrm{SLA}, \mathrm{mm}^{2} \mathrm{mg}^{-1}\right.$ ) was obtained by dividing the total leaf area by the leaf oven dry mass. The ratio of the sapwood area to leaf area was described as the Huber value (HV). 
Table 1: Hakea species investigated showing the life-histories (resprouting ability, leaf form), dominant vegetation type (WWF), biome, mean annual temperature (MAT, ${ }^{\circ} \mathrm{C}$ ), mean annual precipitation (MAP, mm), and mean aridity index (AI).

\begin{tabular}{|c|c|c|c|c|c|c|c|}
\hline Species & $\begin{array}{l}\text { Resprouting } \\
\text { ability }\end{array}$ & Leaf form & Vegetation & Biome & MAT & MAP & $\mathbf{A I}$ \\
\hline Hakea archaeoides & Resprouter & broadleaved & Forest & Humid & 16.82 & 1404 & 0.96 \\
\hline Hakea bucculenta & Non-sprouter & broadleaved & Mediterranean & Arid & 19.56 & 430.9 & 0.16 \\
\hline Hakea cristata & Resprouter & broadleaved & Mediterranean & Arid & 16.66 & 826.5 & 0.41 \\
\hline Hakea dactyloides & Non-sprouter & broadleaved & Forest & Humid & 15.24 & 1033.6 & 0.76 \\
\hline Hakea eyreana & Resprouter & Terete & Arid & Arid & 22.12 & 217.6 & 0.08 \\
\hline Hakea grammatophylla & Resprouter & broadleaved & Arid & Arid & 20.53 & 330.9 & 0.13 \\
\hline Hakea ivoryi & Resprouter & Terete & Grassland & Arid & 20.38 & 361.9 & 0.14 \\
\hline Hakea leucoptera & Resprouter & Terete & Arid & Arid & 19.41 & 294.9 & 0.13 \\
\hline Hakea microcarpa & Non-sprouter & Terete & Forest & Humid & 11.58 & 1015.4 & 0.85 \\
\hline Hakea tephrospermum & Resprouter & Terete & Grassland & Arid & 17.44 & 424.2 & 0.2 \\
\hline Hakea bakeriana & Resprouter & Terete & Forest & Humid & 16.64 & 1123.7 & 0.73 \\
\hline Hakea francisiana & Non-sprouter & broadleaved & Mediterranean & Arid & 18.09 & 303.3 & 0.13 \\
\hline Hakea gibbosa & Non-sprouter & Terete & Forest & Humid & 16.38 & 1202.1 & 0.82 \\
\hline Hakea macraeana & Non-sprouter & Terete & Forest & Humid & 13.61 & 970.2 & 0.8 \\
\hline Hakea salicifolia & Non-sprouter & broadleaved & Forest & Humid & 15.39 & 1191.8 & 0.81 \\
\hline Hakea trifurcata & Non-sprouter & Terete & Mediterranean & Arid & 17.03 & 588.4 & 0.33 \\
\hline
\end{tabular}

\section{Determination of drought tolerance}

Drought tolerance was determined by vulnerability to xylem cavitation $\left(\mathrm{P}_{50}\right)$ using the centrifuge method to induce cavitation in the xylem (Cochard et al., 2013, 2005). This advanced centrifuge technique creates centrifugal force that generates tension in the branch xylem vessels to induce 
cavitation in branch segment, thereby allowing measurement of xylem percentage loss of conductivity at set points of tension. Straight stems, $27 \mathrm{~cm}$ in length and with $6 \mathrm{~mm}$ basal diameter, were sampled and cut under water from the remaining $40 \mathrm{~cm}$-long branch segments, placed on the custom-built rotor and spun at different velocities. To control for the artefact associated with the centrifuge, initial measurements were obtained at lower pressures (-0.5 MPa $=2378 \mathrm{rpm}$ ) that did not induce cavitation (López et al., 2019). The percent loss of conductance (PLC) at negative xylem pressure (tension) was automatically recorded through a step-wise increase (1000 rpm each) at ca. 2 min stabilization time (Zhang et al., 2017) until 90-95\% loss of conductivity was attained. At each new xylem pressure (tension), hydraulic conductance (Kh) was measured from 30 repeated measures. The PLC was computed as PLC $=100 \times(1-$ $\mathrm{Kh} / \mathrm{Kmax}$ ). The dependence of PLC on xylem pressure was used to generate vulnerability curves for each species and $50 \%$ loss of conductance $\left(\mathrm{P}_{50}\right)$ were obtained from slope of the curve using the fitplc R package (Duursma \& Choat, 2017).

\section{Statistical Analysis}

Stem $\mathrm{P}_{50}$ difference between species were tested using a linear model $(\mathrm{lm})$, while differences between biome, life histories traits (resprouting ability and leaf forms), as well as interactions, were determined using a linear mixed effect model (lme4) R package (Bates et al., 2015) with species as a random variable. Residuals of models were inspected; appropriate transformations were conducted and extreme outliers were removed where necessary. ANOVA for mixed effects models was undertaken using Kenward Roger degrees of freedom approximation. Linear mixed effects model with species as random effect was used to explore predictors of cavitation resistance $\left(\mathrm{P}_{50}\right)$. Posthoc Tukey tests were undertaken using the emmeans $\mathrm{R}$ package (Lenth, 2020) to determine which species and life histories are significantly different. 


\section{Results}

\section{Variation in stem $P_{50}$ between species, biome, and vegetation}

There were significant differences in stem $\mathrm{P}_{50}$ between Hakea species $\left(\mathrm{P}<0.001, \mathrm{R}^{2}=0.98\right.$, Table 2; Fig S5 supporting information). There was a continuous variation in $\mathrm{P}_{50}$ across the 16 species sampled and $\mathrm{P}_{50}$ varied 1.9-fold among species from $-4.27 \mathrm{MPa}$ (minimum $\mathrm{P}_{50}, H$. archaeoides to -7.99 $\mathrm{MPa}$ (maximum $\mathrm{P}_{50}, H$. grammatophylla) (Fig 1). Vegetation type was a significant factor in determining stem $\mathrm{P}_{50}\left(\mathrm{P}=0.03, \mathrm{R}^{2}=0.45\right.$; Table 2$)$, such that species from the arid $(-6.61 \pm 0.42)$, mediterranean $(-6.89 \pm 0.23)$ and grassland vegetation $(-7.15 \pm 0.16)$ were more drought tolerant than forest species $(-5.17 \pm 0.17)$. As predicted, there were significant differences in stem $\mathrm{P}_{50}$ between biomes $(\mathrm{P}=0.002$, Table 2, Fig 1$)$, such that species in arid biomes $(-6.86 \pm 0.18)$ were more drought tolerant than species in humid biomes $(-5.17 \pm 0.17$, Fig 1). Biome differences explained $47 \%$ of the variation in stem $P_{50}$. The arid biome had greater variation among species (-7.99 $\mathrm{MPa} H$. grammatophylla to $-5.07 \pm 0.06 \mathrm{MPa} H$. eyreana; Table 3), compared to the humid biome (-6.65 MPa H. macraeana to -4.27 MPa H. archaeoides; Table 3). 
Table 2: Analysis of variance for stem $\mathrm{P}_{50}$ testing for differences among species, biomes, vegetation, resprouting ability and leaf form.

\begin{tabular}{lcccc}
\hline Factors & $\mathbf{F}$ & $\mathbf{D f}$ & $\mathbf{R}^{2}$ & $\mathbf{P}$ \\
\hline Species & & & & \\
\hline Biome & 145.81 & 15 & 0.98 & $2.20 \mathrm{E}-16$ \\
\hline Vegetation & 14.18 & 1 & 0.47 & 0.002 \\
\hline Resprouting ability & 4.31 & 3 & 0.45 & 0.028 \\
\hline Leaf form & 0.17 & 1 & 0.01 & 0.688 \\
\hline Biome & 0.02 & 1 & 0.00 & 0.888 \\
Leaf form & 20.61 & 1 & & 0.0007 \\
Leaf form : Biome & 0.03 & 1 & 0.63 & 0.866 \\
\hline Biome & 8.41 & 1 & & 0.013 \\
Resprouting ability & 13.47 & 1 & & 0.003 \\
Resprouting ability : Biome & 0.12 & 1 & & 0.732 \\
& & & & \\
\hline
\end{tabular}

Each section represents a single model, single factor analysis or analysis with two factors and interaction term. ${ }^{1}$ linear model $(\mathrm{lm})$ for species, while all other models are include speceis as a random factor (lme). 
Table 3: Hakea species biome, vegetation and life history presented alongside mean (+/- SE) cavitation resistance (stem $\left.\mathrm{P}_{50}\right)$ and functional traits.

\begin{tabular}{|c|c|c|c|c|c|c|c|c|c|}
\hline Species & Biome & Vegetation & $\begin{array}{l}\text { Resprouting } \\
\text { ability }\end{array}$ & Leaf form & $\begin{array}{l}P_{50} \\
\text { (-Mpa) }\end{array}$ & $\begin{array}{l}\text { Wood } \\
\text { density } \\
\left(\mathrm{mg} \mathrm{mm}^{-3}\right)\end{array}$ & $\begin{array}{l}\text { SLA } \\
\left(\mathrm{mm}^{2} \mathrm{mg}^{-1}\right)\end{array}$ & $\begin{array}{l}\text { Mean } \\
\text { individual leaf } \\
\text { size }\left(\mathrm{cm}^{2}\right) \text { (per } \\
40 \mathrm{~cm} \text { branch } \\
\text { length) }\end{array}$ & HV $\left(\times 10^{-4}\right)$ \\
\hline Hakea bucculenta & Arid & Mediterranean & Resprouter & Broadleaved & $7.51 \pm 0.04$ & $1.19 \pm 0.08$ & $2.31 \pm 0.4$ & $124.02 \pm 8.4$ & $6.66 \pm 0.28$ \\
\hline Hakea cristata & Arid & Mediterranean & Non-sprouter & Broadleaved & $6.44 \pm 0.06$ & $2.56 \pm 0.13$ & $3.29 \pm 0.41$ & $789.29 \pm 79.9$ & $2.23 \pm 0.11$ \\
\hline Hakea eyreana & Arid & Arid & Resprouter & Broadleaved & $5.07 \pm 0.06$ & $1.23 \pm 0.09$ & $1.22 \pm 0.05$ & $242.81 \pm 15.9$ & $5.86 \pm 0.42$ \\
\hline Hakea francisiana & Arid & Mediterranean & Resprouter & Terete & $7.73 \pm 0.1$ & $1.53 \pm 0.14$ & $2.28 \pm 0.17$ & $162.72 \pm 13.6$ & $3.82 \pm 0.43$ \\
\hline Hakea grammatophylla & Arid & Arid & Non-sprouter & Terete & $7.99 \pm 0.04$ & $3.67 \pm 0.25$ & $5.95 \pm 1.45$ & $505.20 \pm 39.8$ & $2.14 \pm 0.06$ \\
\hline Hakea ivoryi & Arid & Grassland & Resprouter & Terete & $6.80 \pm 0.04$ & $1.41 \pm 0.03$ & $1.69 \pm 0.07$ & $176.21 \pm 6.6$ & $5.78 \pm 0.23$ \\
\hline Hakea leucoptera & Arid & Arid & Resprouter & Terete & $6.78 \pm 0.02$ & $5.12 \pm 0.54$ & $0.60 \pm 0.03$ & $32.18 \pm 99.9$ & $20.89 \pm 1.91$ \\
\hline Hakea tephrosperma & Arid & Grassland & Non-sprouter & Broadleaved & $7.50 \pm 0.04$ & $1.34 \pm 0.05$ & $2.65 \pm 0.2$ & $96.99 \pm 6.6$ & $8.51 \pm 0.14$ \\
\hline Hakea trifurcata & Arid & Mediterranean & Non-sprouter & Terete & $5.91 \pm 0.11$ & $2.19 \pm 0.07$ & $3.06 \pm 0.15$ & $103.78 \pm 5.4$ & $5.09 \pm 0.17$ \\
\hline Hakea archaeoides & Humid & Forest & Resprouter & Broadleaved & $4.27 \pm 0.07$ & $2.30 \pm 0.20$ & $2.35 \pm 0.33$ & $440.74 \pm 40.3$ & $3.56 \pm 0.7$ \\
\hline Hakea bakeriana & Humid & Forest & Non-sprouter & Broadleaved & $5.16 \pm 0.27$ & $1.54 \pm 0.09$ & $2.14 \pm 0.02$ & $251.35 \pm 6.9$ & $3.36 \pm 0.25$ \\
\hline Hakea dactyloides & Humid & Forest & Resprouter & Terete & $4.88 \pm 0.03$ & $1.78 \pm 0.13$ & $6.14 \pm 0.39$ & $145.56 \pm 7.8$ & $3.43 \pm 0.46$ \\
\hline Hakea gibbosa & Humid & Forest & Resprouter & Terete & $5.44 \pm 0.09$ & $1.42 \pm 0.18$ & $2.30 \pm 0.05$ & $129.17 \pm 9.5$ & $2.74 \pm 0.43$ \\
\hline Hakea macraeana & Humid & Forest & Non-sprouter & Broadleaved & $6.65 \pm 0.07$ & $1.80 \pm 0.18$ & $2.70 \pm 0.21$ & $241.59 \pm 25.1$ & $1.62 \pm 0.08$ \\
\hline Hakea microcarpa & Humid & Forest & Non-sprouter & Terete & $5.44 \pm 0.02$ & $3.08 \pm 0.25$ & $2.17 \pm 0.08$ & $62.57 \pm 4.4$ & $2.52 \pm 0.25$ \\
\hline Hakea salicifolia & Humid & Forest & Non-sprouter & Terete & $4.37 \pm 0.19$ & $1.27 \pm 0.05$ & $4.88 \pm 0.22$ & $298.57 \pm 31.5$ & $2.33 \pm 0.08$ \\
\hline
\end{tabular}




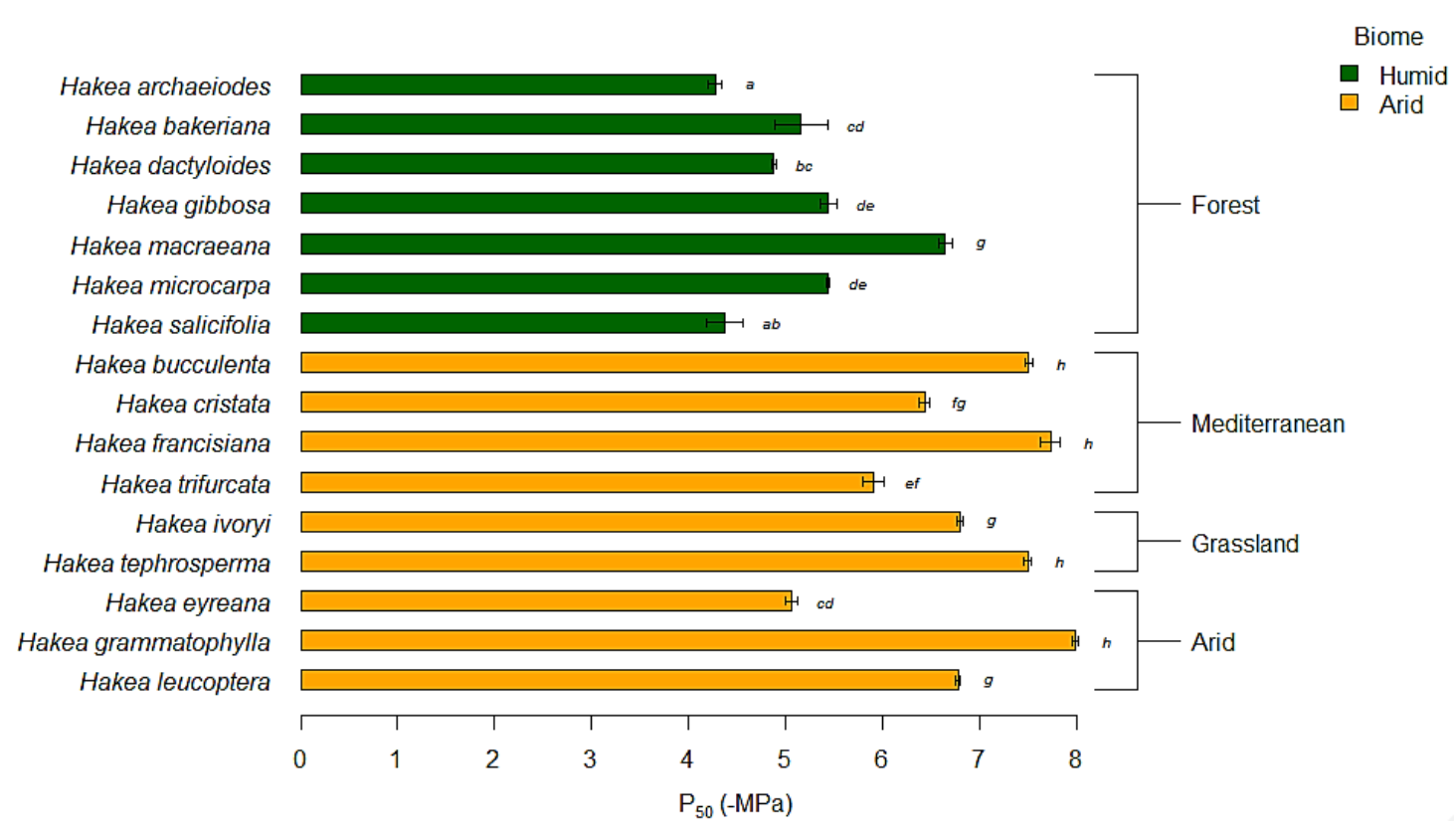

Fig 1: Stem $\mathrm{P}_{50}$ of Hakea species in the different biomes and vegetation types. Values presented are mean \pm standard error of each species. Colours and brackets show the different biome and vegetation type, respectively. Letters denote which categories are significantly different based on a Post-hoc Tukey's test.

\section{Cavitation resistance (stem $\mathbf{P}_{50}$ ) related to biome and life histories}

There was no significant difference in $\mathrm{P}_{50}$ between life history types (resprouters vs nonsprouters, $\mathrm{P}=0.688$; broadleaved vs terete leaves, $\mathrm{P}=0.888$; Table 2 ). However, there was a significant interaction between biome and leaf form for stem $\mathrm{P}_{50}(\mathrm{P}=0.013$; Table 2$)$. Broadleaved species in the arid biome were significantly more drought tolerant than broad and terete leaved species in the humid biome, whilst broadleaved species in the humid biome were significantly less drought tolerant than both leaf forms in the arid biome (Fig 2). Such that drought tolerance increased from the humid biome broad to terete leaved species then to the arid biome terete to broad leaved species. No significant interaction between resprouting ability and biome was detected (Table 2), however non-sprouting and resprouting species in the arid biome were more drought tolerant than resprouters in the humid biome (Fig 2). 

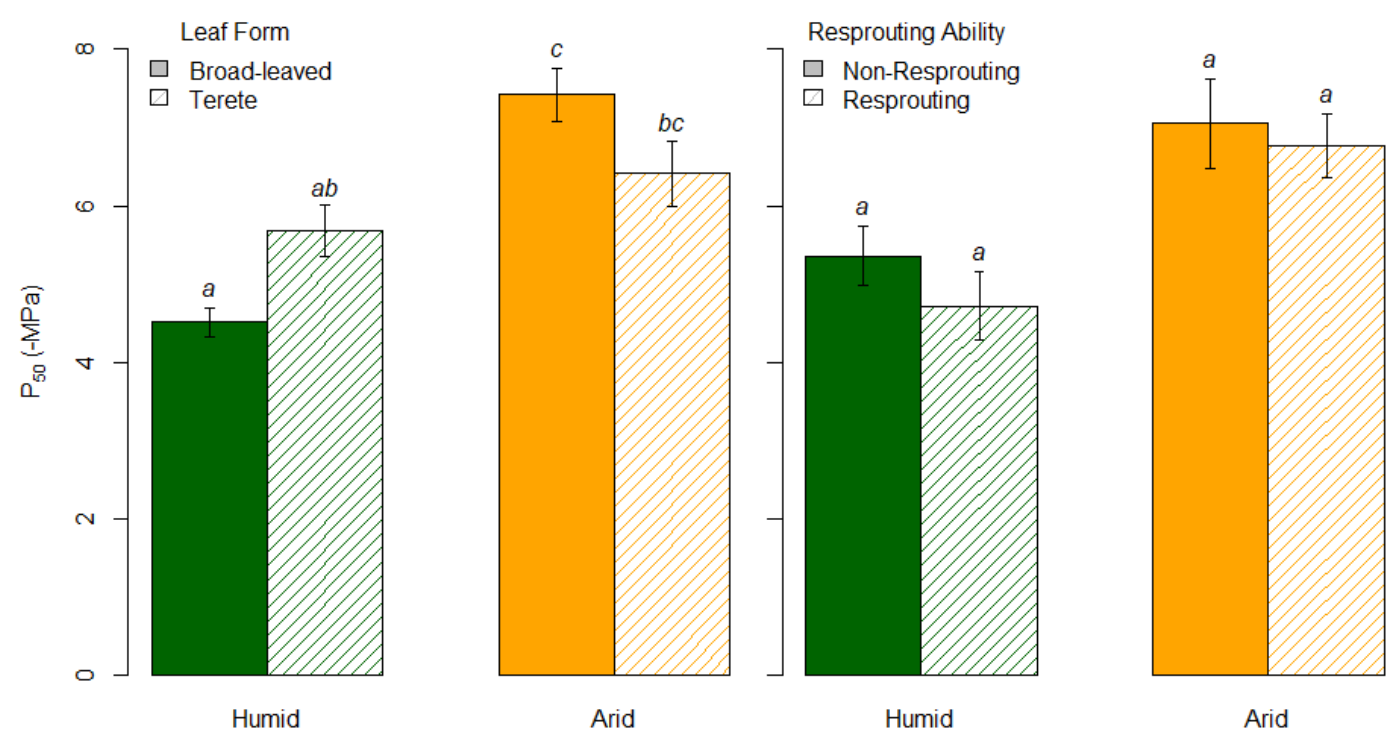

Fig 2: Interaction between biome and leaf form (a), and biome and resprouting ability (b) for cavitation resistance (stem $\mathrm{P}_{50}$ mean \pm standard error). Letters denote which categories are significantly different based on a Post-hoc Tukey's test.

\section{Interplay between drought tolerance, functional traits and climatic origin}

$\mathrm{P}_{50}$ and $\mathrm{HV}$ were significantly correlated with species climate-origin. Drought tolerance (stem $\mathrm{P}_{50}$ ) was significantly related with rainfall $\left(\mathrm{MAP} \mathrm{R}^{2}=0.51, \mathrm{P}\right.$-value $\left.=0.001\right)$ and aridity $\left(\mathrm{AI} \mathrm{R}^{2}=\right.$ 0.49$, P-value $=0.001)$, but unrelated with temperature $\left(\mathrm{MAT} \mathrm{R}^{2}=0.13, \mathrm{P}\right.$-value $\left.=0.143\right)($ Fig 3 $a, b, c)$. Variation in stem $\mathrm{P}_{50}$ was not significantly related to any functional traits; WD, SLA, leaf area and HV (Fig S4, supporting information). Similar to stem $\mathrm{P}_{50}$, HV was significantly related to MAP $\left(R^{2}=0.24, P=0.04\right), A I\left(R^{2}=0.22, P=0.04\right)$ but unrelated with MAT $\left(R^{2}=\right.$ $0.156, \mathrm{P}=0.111$ ) (Fig $3 \mathrm{~d}, \mathrm{e}, \mathrm{f}$ ). Wood density, SLA and leaf size were not found to be significantly related to any of the climate variables. 


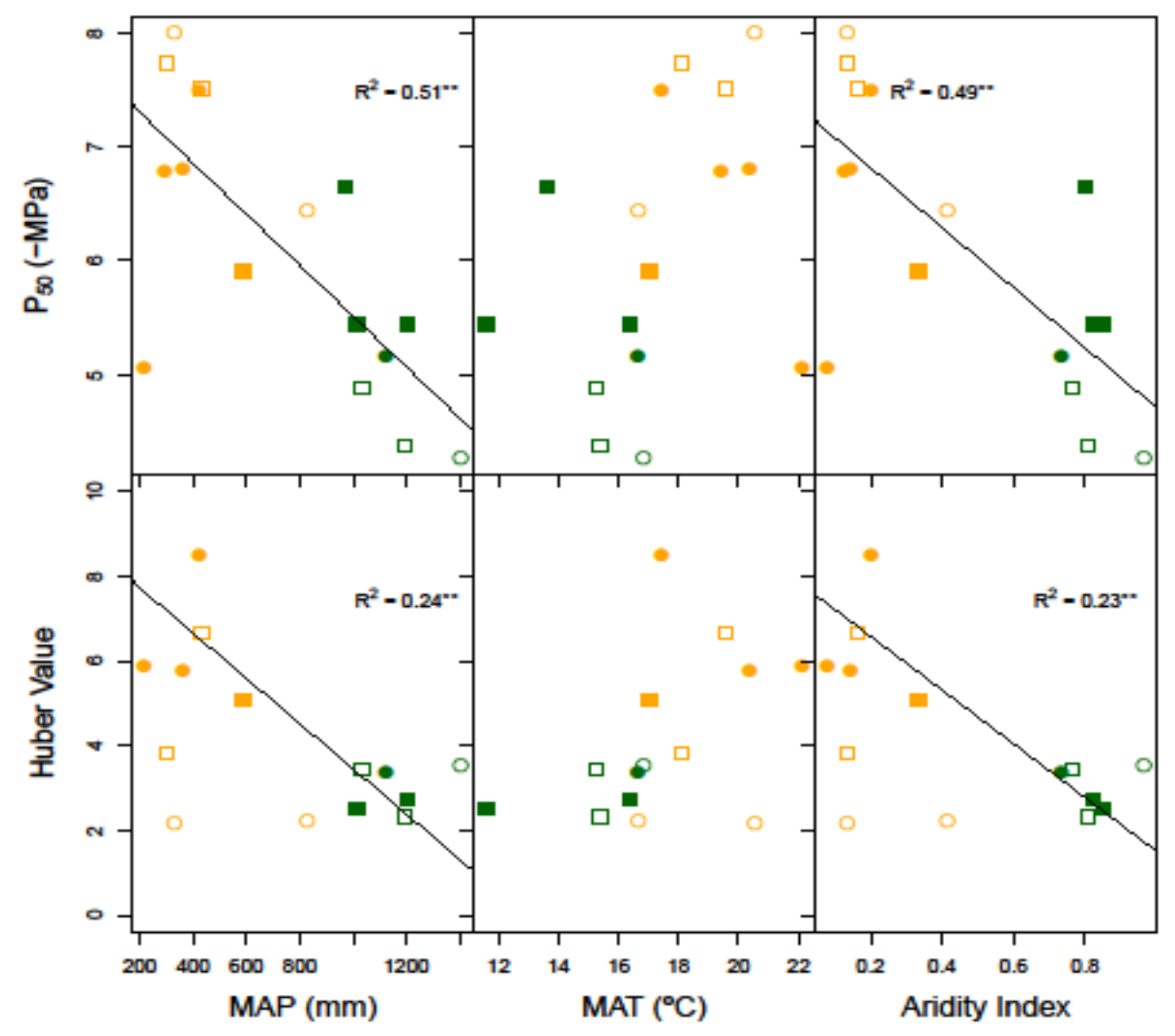

Fig 3: Relationship between stem water potential causing 50\% loos of conductance (P50; panels a, b, c) and Huber Value (HV x 10^-4; panels d, e, f) with rainfall (MAP), temperature (MAT) and aridity (AI) of the species climate-origin. Values presented are mean of each species colour coded for different biomes (green $=$ humid, orange $=$ arid) with different shapes for life-histories $($ circle $=$ resprouters, rectangle $=$ non-resprouters $)$ and different fill for leaf form (filled $=$ terete, open $=$ broadleaved $)$. Significance codes: ${ }^{‘ * *}{ }^{\prime}, \mathbf{P}<\mathbf{0 . 0 1},{ }^{6 *}{ }^{\prime}, \mathbf{P}<\mathbf{0 . 0 5}$. 


\section{Discussion}

The aim of this study was to determine the drought tolerance of a diverse array of Hakea species to test prediction based on climate-origin and life-history. Sampling 16 Hakea species representing a wide range of climatic niche and life history traits from common conditions estimated genetically determined trait variation. Our results revealed that there was significant variation in the drought tolerance of congeneric species and that biome/climate (rainfall and aridity) of origin was the key predictor of hydraulic traits (stem $\mathrm{P}_{50}$ ). Other traits contributed to drought tolerance; terete leaf form and higher sapwood area to leaf area ratio (HV) would be expected to reduce whole plant exposure and stress during periods of high evaporative demand. The study is timely given the recent devastating drought episodes experienced across the Australian continent, and in many regions throughout the world.

\section{Climate is a major driver of variation in cavitation resistance}

Climate has often been highlighted as the key driver of species variation in hydraulic traits (Li et al., 2018). Hydraulic traits appear to be adaptive with species that have shorter and narrower vessels tending to occupy drier biomes and have lower vulnerability to cavitation (Christman et al., 2009; Larter et al., 2017; Lens et al., 2011, 2009; Pockman and Sperry, 2000; Skelton et al., 2018; Sperry et al., 2008; Wheeler et al., 2007). In this study, species in the arid biome/climate (with the potential exception of $H$. eyreana) generally had higher cavitation resistance $\left(\mathrm{P}_{50}\right.$ below -6.75 MPa) compared with species in the humid biome (Table 3). This was indeed expected as species within the arid biome possess traits that confer greater drought tolerance (Choat et al., 2012; Li et al., 2019, 2018; Trueba et al., 2017). To understand if drought tolerance is genetically determined hydraulic trait, we plotted $\mathrm{P}_{50}$ against mean annual precipitation (MAP), temperature (MAT), and aridity (AI) across the species distribution range (Fig 3). We found evidence 
supporting our expectation, that drought tolerance trait $\mathrm{P}_{50}$ is significantly related with climate (Bourne et al., 2017; Choat et al., 2012; Larter et al., 2017; Li et al., 2018; Maherali et al., 2004; Trueba et al., 2017). Our results revealed that rainfall and aridity were key drivers of the variation in species $\mathrm{P}_{50}$ within the diverse Hakea genus, such that species cavitation resistance increases with reduced rainfall of species climatic origin. Furthermore, the $\mathrm{P}_{50}$ trait variation measured in a common garden provides strong evidence that drought tolerance is geneticallydetermined and adaptive (Lamy et al., 2014; Li et al., 2018; López et al., 2016; Skelton et al., 2019). Hence, cavitation is a key factor shaping species distribution with respect to water availability (Brodribb and Hill, 1999).

\section{Variation in species cavitation resistance across life history traits}

We observed significant species-specific variation in cavitation resistance among Hakea species (Table 2), demonstrating that species within the genus vary broadly in their capacity to tolerate high levels of water stress. Differences in species drought tolerance (stem P50) are largely attributed to the differences in the xylem structure; e.g. pit membrane porosity and thickness, and conduit size (Choat et al., 2012, 2008; Delzon et al., 2010; Li et al., 2016; Maherali et al., 2004; Sperry et al., 2006). At maturity, xylem conduits are dead with no possible acclimation to environmental change, making estimates of drought tolerance via embolism resistance very important to make reliable prediction under future climatic changes (Choat et al., 2012).

Species habitat preference and survival under disturbances (e.g. fire and drought) within the Hakea genus have previously been reported to be related with species life history and leaf form (Groom and Lamont, 1996). In contrast to our expectation, there were no significant differences between resprouters and non-resprouters, as well as broad and terete leaved species (Table 2). Previous studies have reported contrary findings in relation to resprouting ability and drought 
tolerance (Vilagrosa et al., 2014; Zeppel et al., 2015). The differences between these studies and our study may be due to the fact that Zeppel et al (2015) considered a large database of stem $\mathrm{P}_{50}$ with species across different genus, indicating that resprouters were more drought tolerant than non-resprouters, at least within Angiosperms. On the other hand, Vilagrosa et al. (2014) used field observation and stem hydraulic measurements focusing on 12 co-occurring woody species within the Mediterranean system found that resprouters were less drought tolerant than nonresprouters (i.e. seeders), in direct contrast to Zeppel et al. (2015). In contrast to these studies, we focused on a single genus across multiple biomes finding no difference in drought tolerance with resprouting ability. This finding is partially supported by Groom and Lamont (1996), who found resprouting ability among Hakea species within the Mediterranean biome of southwest Australia was not associated with aridity. The differences may be due to varying drought strategies (i.e. tolerators, avoiders) for survival among genera and biomes.

\section{Interactions between leaf form and biome}

Arid plants show adaptations with small, terete, leaves, as seen in the distribution of Hakea species in the southwest Australian Mediterranean biome (Groom and Lamont 1996). While our findings do not support this overall pattern, we observed a significant interaction between leaf form and biome for drought tolerance. Broad-leaved species in the arid biome were significantly more drought tolerant compared to broad-leaved species in the humid biome (Fig 2). Broad leaves increase the surface area for carbon uptake (photosynthesis) and transpiration, however within warmer and drier sites, this may potentially lead to serious water loss or cavitation (Wright et al., 2017). Thus, broadleaved species within the arid biome would be more dependent on resistant xylem (higher $\mathrm{P}_{50}$ ) to prevent implosion. Our results also showed support for this (though not significant), as broadleaved species within the arid biome generally had higher $\mathrm{P}_{50}$ 
compared to terete leaved species in the same biome (Fig 2). This finding highlights the ability for different strategies to co-exist in the arid biome, and the importance of understanding trait coordination alongside climate drivers for drought adaptation.

\section{Avoidance of water stress as a possible strategy to persist in the arid biome}

Huber value (HV, ratio of sapwood to leaf area) is a measure of carbon investment in xylem tissue per unit leaf area (Eamus et al., 2006; Gotsch et al., 2010; Pérez-Harguindeguy et al., 2013). Knowledge of the HV gives insight into the strategy species employed to survive in varying climate, as such reduced leaf area to sapwood area ratio implies avoidance strategy (Eamus et al., 2006). Species in the arid biome may employ drought avoidance strategy in addition to tolerance to persist in the arid biome (Fig 3). This was indeed true as HV was significantly related to climate (MAP, AI), such that species with higher HV tended to occupy areas with reduced rainfall, inferring greater demand for water transport (Choat et al., 2007; Gleason et al., 2012). Studies have also shown variation in drought tolerance traits within communities irrespective of the precipitation level (Maherali et al., 2004; McCulloh et al., 2019). This is true, as we observed wide variation in $\mathrm{P}_{50}$ within the Arid-Arid communities (or vegetation-biome, Table 3) driven by the low stem $\mathrm{P}_{50}$ value of $H$. eyreana. We also observed the wood density of $H$. eyreana $(1.23 \pm 0.09)$ to be about 3 -fold smaller than $H$. leucoptera and 4.1-fold smaller than $H$. grammatophylla which also possesses a higher $\mathrm{P}_{50}$, suggesting that $H$. eyreana may probably employ a different strategy (e.g. drought avoidance) to survive in the arid biome. Hakea eyreana may have different trait coordination or trade-offs among traits along the water transport pathway under field scenarios or in response to the experimental (well-watered) condition (Brodribb et al., 2017; Li et al., 2018; McCulloh et al., 2019). Traits including life history (e.g. resprouting ability and leaf form), growth form (e.g. liana vs tree), stomatal 
regulation, soil water depth, and root depth may also offset the need for developing more negative stem $\mathrm{P}_{50}$ (Bartletta et al., 2016; Meinzer et al., 2009; Padilla and Pugnaire, 2007; Skelton et al., 2015). We found evidence that drought avoidance provided with terete leaf form and reduced leaf area to sapwood ratio (HV) may enable species with low drought tolerance (e.g. H. eyreana) the ability to persist in the arid biome. The plots of $\mathrm{HV}$ and $\mathrm{P}_{50}$ against aridity showing different life-histories (Fig 3) are informative in understanding different drought strategies. These traits may balance the need for carbon capture and growth with the demand for developing xylem resistant to drought (high $\mathrm{P}_{50}$, $-\mathrm{MPa}$ ) for colonization and persistence in the arid biome.

\section{Relationship between cavitation resistance and functional traits}

Surprisingly, we observed no significant relationship between $\mathrm{P}_{50}$ and functional traits (e.g. wood density, SLA, HV, LDMC; Fig S4 supporting information) (Hacke et al., 2001; Markesteijn et al., 2011; Schumann et al., 2019; Villagra et al., 2013). Of these functional traits, wood density has received more attention in relation to drought tolerance as greater structural investment (wood density) would prevent xylem implosion, and thus greater resistance to embolism (Hacke et al., 2001; Li et al., 2018; Markesteijn et al., 2011). However, some other studies have also reported no significant association between wood density and $\mathrm{P}_{50}$ (Larter et al., 2017; Trueba et al., 2017). The non-significant relationships between $\mathrm{P}_{50}$ and functional traits (e.g. WD and SLA) found by Trueba et al. (2017) may be because species were pooled from diverse communities and genera. Furthermore, there may be limited selective pressure for investment in structural strength since our study sites were well-watered, as studies have shown environment or site to be a determinant of wood density (Downes et al., 2006; Onoda et al., 2010; Roderick and Berry, 2002; Searson et al., 2004; Wimmer et al., 2002). 
Leaf size traits were not important in pooling species apart in relation to stem $\mathrm{P}_{50}$, as both broadleaved and terete leaved species are distributed within the arid and humid communities (Groom and Lamont, 1996). However, in combination with Huber value, leaf size may be important in highlighting species strategy to drought and across climate/biomes. For instance in arid biome, species with reduced leaf area to sapwood area employs avoidance strategy, while species with greater surface area within the same system will tend to prioritize the construction of xylem resistance to embolism (i.e higher stem $\mathrm{P}_{50}$ ) for survival. Interestingly, we did not observe significant relationships between hydraulic traits $\left(\mathrm{HV}\right.$ and $\left.\mathrm{P}_{50}\right)$. However, the direction of the relationship was positive $\left(\mathrm{R}^{2}=0.14, \mathrm{P}\right.$ value $\left.=0.588\right)$ as expected $($ Carter and White, 2009; Markesteijn et al., 2011). The weak relationship suggests that not all species with higher $\mathrm{P}_{50}$ (tolerance) necessarily had higher HV (avoidance) (Fig S4, supporting information), as some species may either employ alternate strategies for survival.

\section{Conclusion}

This study highlights climate (rainfall and aridity), rather than life history and functional traits, as the key predictor of variation in drought tolerance (stem $\mathrm{P}_{50}$ ). Rainfall for species origin was the best predictor of hydraulic trait, explaining variation in stem $\mathrm{P}_{50}$, which appears to be a major determinant of species distribution. This study also indicates that stem $\mathrm{P}_{50}$ is an adaptive trait, genetically determined, and hence reliable and robust for predicting species vulnerability to climate change. This provides support for climate as a predictor of species suitability under climate change using species distribution models. Our results show that Hakea species in humid biomes are more vulnerable to future droughts compared to species in arid biomes. Alternative 
avoidance or recovery strategies may still be important for diverse flora to colonise and persist in the arid biome. We provide evidence for avoidance via terete leaves and enhanced HV, however the role of resprouting in recovery from drought was not supported. Findings from this study will provide the scientific basis for adaptive management strategies for Hakea, including conservation of threatened and widespread species through translocations and assisted migration respectively.

Acknowledgement: We appreciate the support of Benedict Lyte from The Australian Botanic Garden, Mount Annan for granting us excess to their collections and Nzie Peter for support in data collection and Rosana Lopez for technical insights into the hydraulic techniques. Australian Postgraduate Award (Western Sydney University), Ecological Society of Australia-Holsworth Wildlife Research Endowment grant to O.O.O and NSW Department for Planning, Industry and Environment, Saving Our Species grant to P.D.R and D.T. 


\section{References}

Adams, H.D., Zeppel, M.J.B., Anderegg, W.R.L., Hartmann, H., Landhäusser, S.M., Tissue, D.T., Huxman, T.E., Hudson, P.J., Franz, T.E., Allen, C.D., Anderegg, L.D.L., BarronGafford, G.A., Beerling, D.J., Breshears, D.D., Brodribb, T.J., Bugmann, H., Cobb, R.C., Collins, A.D., Dickman, L.T., Duan, H., Ewers, B.E., Galiano, L., Galvez, D.A., Garcia-

Forner, N., Gaylord, M.L., Germino, M.J., Gessler, A., Hacke, U.G., Hakamada, R., Hector, A., Jenkins, M.W., Kane, J.M., Kolb, T.E., Law, D.J., Lewis, J.D., Limousin, J.-M., Love, D.M., Macalady, A.K., Martínez-Vilalta, J., Mencuccini, M., Mitchell, P.J., Muss, J.D., O’Brien, M.J., O’Grady, A.P., Pangle, R.E., Pinkard, E.A., Piper, F.I., Plaut, J.A., Pockman, W.T., Quirk, J., Reinhardt, K., Ripullone, F., Ryan, M.G., Sala, A., Sevanto, S., Sperry, J.S., Vargas, R., Vennetier, M., Way, D.A., Xu, C., Yepez, E.A., McDowell, N.G., 2017. A multi-species synthesis of physiological mechanisms in drought-induced tree mortality. Nat. Ecol. Evol. 1, 1285-1291. https://doi.org/10.1038/s41559-017-0248-X

Allen, C.D., Macalady, A.K., Chenchouni, H., Bachelet, D., McDowell, N., Vennetier, M., Kitzberger, T., Rigling, A., Breshears, D.D., Hogg, E.H. (Ted., Gonzalez, P., Fensham, R., Zhang, Z., Castro, J., Demidova, N., Lim, J.H., Allard, G., Running, S.W., Semerci, A., Cobb, N., 2010. A global overview of drought and heat-induced tree mortality reveals emerging climate change risks for forests. For. Ecol. Manage. 259, 660-684. https://doi.org/10.1016/j.foreco.2009.09.001

Anderegg, W.R.L., Klein, T., Bartlett, M., Sack, L., Pellegrini, A.F.A., Choat, B., Jansen, S., 2016. Meta-analysis reveals that hydraulic traits explain cross-species patterns of drought- 
induced tree mortality across the globe. Proc. Natl. Acad. Sci. U. S. A. 113, 5024-5029. https://doi.org/10.1073/pnas.1525678113

Barotto, A.J., Monteoliva, S., Gyenge, J., Martinez-Meier, A., Fernandez, M.E., 2018.

Functional relationships between wood structure and vulnerability to xylem cavitation in races of Eucalyptus globulus differing in wood density. Tree Physiol. 38, 243-251. https://doi.org/10.1093/treephys/tpx138

Bartletta, M.K., Klein, T., Jansen, S., Choat, B., Sack, L., Bartlett, M.K., Klein, T., Jansen, S., Choat, B., Sack, L., 2016. The correlations and sequence of plant stomatal, hydraulic, and wilting responses to drought. Proc. Natl. Acad. Sci. U. S. A. 113, 13098-13103. https://doi.org/10.1073/pnas.1604088113

Bates, D., Mächler, M., Bolker, B.M., Walker, S.C., 2015. Fitting Linear Mixed-Effects Models Using lme4 67. https://doi.org/10.18637/jss.v067.i01

Blackman, C.J., Aspinwall, M.J., Tissue, D.T., Rymer, P.D., 2017. Genetic adaptation and phenotypic plasticity contribute to greater leaf hydraulic tolerance in response to drought in warmer climates. Tree Physiol. 37, 583-592. https://doi.org/10.1093/treephys/tpx005

Blackman, C.J., Gleason, S.M., Chang, Y., Cook, A.M., Laws, C., Westoby, M., 2014. Leaf hydraulic vulnerability to drought is linked to site water availability across a broad range of species and climates. Ann. Bot. 114, 435-440. https://doi.org/10.1093/aob/mcu131

Bourne, A.E., Creek, D., Peters, J.M.R., Ellsworth, D.S., Choat, B., 2017. Species climate range influences hydraulic and stomatal traits in Eucalyptus species. Ann. Bot. 120, 123-133. https://doi.org/10.1093/aob/mcx020 
Brodribb, T., Hill, R.S., 1999. The importance of xylem constraints in the distribution of conifer species. New Phytol. 143, 365-372. https://doi.org/10.1046/j.1469-8137.1999.00446.x

Brodribb, T.J., Cochard, H., 2009. Hydraulic failure defines the recovery and point of death in water-stressed conifers. Plant Physiol. 149, 575-584. https://doi.org/10.1104/pp.108.129783

Brodribb, T.J., Holbrook, N.M., 2004. Stomatal protection against hydraulic failure: a comparison of coexisting ferns and angiosperms. New Phytol. 162, 663-670. https://doi.org/10.1111/j.1469-8137.2004.01060.x

Brodribb, T.J., McAdam, S.A.M., Carins Murphy, M.R., 2017. Xylem and stomata, coordinated through time and space. Plant Cell Environ. 40, 872-880. https://doi.org/10.1111/pce.12817

Carter, J.L., White, D.A., 2009. Plasticity in the Huber value contributes to homeostasis in leaf water relations of a mallee Eucalypt with variation to groundwater depth. Tree Physiol. 29, 1407-1418. https://doi.org/10.1093/TREEPHYS/TPP076

Choat, B., Cobb, A.R., Jansen, S., 2008. Structure and function of bordered pits: New discoveries and impacts on whole-plant hydraulic function. New Phytol. 177, 608-626. https://doi.org/10.1111/j.1469-8137.2007.02317.x

Choat, B., Jansen, S., Brodribb, T.J., Cochard, H., Delzon, S., Bhaskar, R., Bucci, S.J., Feild, T.S., Gleason, S.M., Hacke, U.G., Jacobsen, A.L., Lens, F., Maherali, H., Martínez-Vilalta, J., Mayr, S., Mencuccini, M., Mitchell, P.J., Nardini, A., Pittermann, J., Pratt, R.B., Sperry, J.S., Westoby, M., Wright, I.J., Zanne, A.E., 2012. Global convergence in the vulnerability of forests to drought. Nature 491, 752-755. https://doi.org/10.1038/nature11688

Choat, B., Sack, L., Holbrook, N.M., 2007. Diversity of hydraulic traits in nine Cordia species 
growing in tropical forests with contrasting precipitation. New Phytol. 175, 686-698. https://doi.org/10.1111/j.1469-8137.2007.02137.x

Christman, M.A., Sperry, J.S., Adler, F.R., 2009. Testing the "rare pit" hypothesis for xylem cavitation resistance in three species of Acer. New Phytol. 182, 664-674. https://doi.org/10.1111/j.1469-8137.2009.02776.x

Clarke, P.J., Lawes, M.J., Midgley, J.J., Lamont, B.B., Ojeda, F., Burrows, G.E., Enright, N.J., Knox, K.J.E., 2013. Resprouting as a key functional trait: How buds, protection and resources drive persistence after fire. New Phytol. https://doi.org/10.1111/nph.12001

Cochard, H., 2014. The basics of plant hydraulics. J. Plant Hydraul. 1, 001. https://doi.org/10.20870/jph.2014.e001

Cochard, H., Badel, E., Herbette, S., Delzon, S., Choat, B., Jansen, S., 2013. Methods for measuring plant vulnerability to cavitation: A critical review, Journal of Experimental Botany. https://doi.org/10.1093/jxb/ert193

Cochard, H., Damour, G., Bodet, C., Tharwat, I., Poirier, M., Améglio, T., 2005. Evaluation of a new centrifuge technique for rapid generation of xylem vulnerability curves. Physiol. Plant. 124, 410-418. https://doi.org/10.1111/j.1399-3054.2005.00526.x

Delzon, S., Douthe, C., Sala, A., Cochard, H., 2010. Mechanism of water-stress induced cavitation in conifers: Bordered pit structure and function support the hypothesis of seal capillary-seeding. Plant, Cell Environ. 33, 2101-2111. https://doi.org/10.1111/j.13653040.2010.02208.x

Downes, G., Worledge, D., Schimleck, L., Harwood, C., French, J., Beadle, C., 2006. The effect 
of growth rate and irrigation on the basic density and kraft pulp yield of Eucalyptus globulus and E. nitens. New Zeal. J. For. 51, 13-22.

Eamus, D., Hatton, T., Colvin, P., C., C., 2006. Ecohydrology: Vegetation Function, Water and Resource Management. CSIRO PUBLISHING, Collingwood, Victoria, Australia.

Fitzpatrick, M.C.M.C., Gove, A.D., Sanders, N.J., Dunn, R.R., 2008. Climate change, plant migration, and range collapse in a global biodiversity hotspot: The Banksia (Proteaceae) of Western Australia. Glob. Chang. Biol. https://doi.org/10.1111/j.1365-2486.2008.01559.x

Gleason, S.M., Butler, D.W., Ziemińska, K., Waryszak, P., Westoby, M., 2012. Stem xylem conductivity is key to plant water balance across Australian angiosperm species. Funct. Ecol. 26, 343-352. https://doi.org/10.1111/j.1365-2435.2012.01962.x

Gotsch, S.G., Geiger, E.L., Franco, A.C., Goldstein, G., Meinzer, F.C., Hoffmann, W.A., 2010. Allocation to leaf area and sapwood area affects water relations of co-occurring savanna and forest trees. Oecologia 163, 291-301. https://doi.org/10.1007/s00442-009-1543-2

Goulden, M.L., Bales, R.C., 2019. California forest die-off linked to multi-year deep soil drying in 2012-2015 drought. Nat. Geosci. 12, 632-637. https://doi.org/10.1038/s41561-019-03885

Groom, P.P.K., Lamont, B.B.B., 1996. Ecogeographical analysis of Hakea (proteaceae) in southwestern Australia, with special reference to leaf morphology and life form, Australian Journal of Botany. CSIRO PUBLISHING. https://doi.org/10.1071/BT9960527

Hacke, U.G., Sperry, J.S., Pockman, W.T., Davis, S.D., McCulloh, K.A., 2001. Trends in wood density and structure are linked to prevention of xylem implosion by negative pressure. 
Oecologia 126, 457-461. https://doi.org/10.1007/s004420100628

Hernández, E.I., Pausas, J.G., Vilagrosa, A., 2011. Leaf physiological traits in relation to resprouter ability in the Mediterranean Basin. Plant Ecol. 212, 1959-1966. https://doi.org/10.1007/s11258-011-9976-1

Jacobsen, A.L., Agenbag, L., Esler, K.J., Pratt, R.B., Ewers, F.W., Davis, S.D., 2007. Xylem density, biomechanics and anatomical traits correlate with water stress in 17 evergreen shrub species of the Mediterranean-type climate region of South Africa. J. Ecol. 95, 171183. https://doi.org/10.1111/j.1365-2745.2006.01186.x

Jacobsen, A.L., Ewers, F.W., Pratt, R.B., Paddock III, W.A., Davis, S.D., 2005. Do xylem fibers affect vessel cavitation resistance? Plant Physiol. 139, 546-556. https://doi.org/10.1104/pp.104.058404

Kursar, T.A., Engelbrecht, B.M.J., Burke, A., Tyree, M.T., El Omari, B., Giraldo, J.P., 2009. Tolerance to low leaf water status of tropical tree seedlings is related to drought performance and distribution. Funct. Ecol. 23, 93-102. https://doi.org/10.1111/j.13652435.2008.01483.x

Lamy, J.-B., Delzon, S., Bouche, P.S., Alia, R., Vendramin, G.G., Cochard, H., Plomion, C., 2014. Limited genetic variability and phenotypic plasticity detected for cavitation resistance in a Mediterranean pine. New Phytol. 201, 874-886. https://doi.org/10.1111/nph.12556

Larter, M., Pfautsch, S., Domec, J.-C., Trueba, S., Nagalingum, N., Delzon, S., 2017. Aridity drove the evolution of extreme embolism resistance and the radiation of conifer genus Callitris. New Phytol. 215, 97-112. https://doi.org/10.1111/nph.14545 
Lens, F., Endress, M.E., Baas, P., Jansen, S., Smets, E., 2009. Vessel grouping patterns in subfamilies apocynoideae and periplocoideae confirm phylogenetic value of wood structure within apocynaceae. Am. J. Bot. 96, 2168-2183. https://doi.org/10.3732/ajb.0900116

Lens, F., Sperry, J.S., Christman, M.A., Choat, B., Rabaey, D., Jansen, S., 2011. Testing hypotheses that link wood anatomy to cavitation resistance and hydraulic conductivity in the genus Acer. New Phytol. 190, 709-723. https://doi.org/10.1111/j.14698137.2010.03518.x

Lenth, R., 2020. emmeans: Estimated Marginal Means, aka Least-Squares Means. R package version 1.4.5.

Li, S., Lens, F., Espino, S., Karimi, Z., Klepsch, M., Schenk, H.J., Schmitt, M., Schuldt, B., Jansen, S., 2016. Intervessel Pit Membrane Thickness as a Key Determinant of Embolism Resistance in Angiosperm Xylem. IAWA J. 37, 152-171. https://doi.org/10.1163/22941932-20160128

Li, X., Blackman, C.J., Choat, B., Duursma, R.A., Rymer, P.D., Medlyn, B.E., Tissue, D.T., 2018. Tree hydraulic traits are coordinated and strongly linked to climate-of-origin across a rainfall gradient. Plant Cell Environ. 41, 646-660. https://doi.org/10.1111/pce.13129

Li, X., Blackman, C.J., Choat, B., Rymer, P.D., Medlyn, B.E., Tissue, D.T., 2019. Drought tolerance traits do not vary across sites differing in water availability in Banksia serrata (Proteaceae). Funct. Plant Biol. 46, 624. https://doi.org/10.1071/FP18238

López, R., Cano, F.J., Choat, B., Cochard, H., Gil, L., 2016. Plasticity in Vulnerability to Cavitation of Pinus canariensis Occurs Only at the Driest End of an Aridity Gradient. Front. Plant Sci. 7. https://doi.org/10.3389/fpls.2016.00769 
López, R., Nolf, M., Duursma, R.A., Badel, E., Flavel, R.J., Cochard, H., Choat, B., 2019. Mitigating the open vessel artefact in centrifuge-based measurement of embolism resistance. Tree Physiol. 39, 143-155. https://doi.org/10.1093/treephys/tpy083

Lucani, C.J., Brodribb, T.J., Jordan, G., Mitchell, P.J., 2019. Intraspecific variation in drought susceptibility in Eucalyptus globulus is linked to differences in leaf vulnerability. Funct. Plant Biol. 46, 286. https://doi.org/10.1071/FP18077

Maherali, H., Pockman, W.T., Jackson, R.B., 2004. Adaptive variation in the vulnerability of woody plants to xylem cavitation. Ecology 85, 2184-2199. https://doi.org/10.1890/02-0538

Markesteijn, L., Poorter, L., Paz, H., Sack, L., Bongers, F., 2011. Ecological differentiation in xylem cavitation resistance is associated with stem and leaf structural traits. Plant, Cell Environ. 34, 137-148. https://doi.org/10.1111/j.1365-3040.2010.02231.x

Martin-StPaul, N., Delzon, S., Cochard, H., 2017. Plants resistance to drought relies on early stomata closure. bioRxiv 99531.

Martorell, S., Diaz-Espejo, A., Medrano, H., Ball, M.C., Choat, B., 2014. Rapid hydraulic recovery in Eucalyptus pauciflora after drought: Linkages between stem hydraulics and leaf gas exchange. Plant, Cell Environ. 37, 617-626. https://doi.org/10.1111/pce.12182

McCulloh, K.A., Domec, J., Johnson, D.M., Smith, D.D., Meinzer, F.C., 2019. A dynamic yet vulnerable pipeline: Integration and coordination of hydraulic traits across whole plants. Plant. Cell Environ. pce.13607. https://doi.org/10.1111/pce.13607

McDowell, N., Pockman, W.T., Allen, C.D., Breshears, D.D., Cobb, N., Kolb, T., Plaut, J., Sperry, J., West, A., Williams, D.G., Yepez, E.A., 2008. Mechanisms of plant survival and 
mortality during drought: Why do some plants survive while others succumb to drought? New Phytol. 178, 719-739. https://doi.org/10.1111/j.1469-8137.2008.02436.x

Meinzer, F.C., Johnson, D.M., Lachenbruch, B., Mcculloh, K.A., Woodruff, D.R., 2009. Xylem hydraulic safety margins in woody plants: Coordination of stomatal control of xylem tension with hydraulic capacitance. Funct. Ecol. 23, 922-930. https://doi.org/10.1111/j.1365-2435.2009.01577.x

Moreira, B., Tormo, J., Pausas, J.G., 2012. To resprout or not to resprout: Factors driving intraspecific variability in resprouting. Oikos 121. https://doi.org/10.1111/j.16000706.2011.20258.x

Nardini, A., Luglio, J., 2014. Leaf hydraulic capacity and drought vulnerability: Possible tradeoffs and correlations with climate across three major biomes. Funct. Ecol. 28, 810-818. https://doi.org/10.1111/1365-2435.12246

Onoda, Y., Richards, A.E., Westoby, M., 2010. The relationship between stem biomechanics and wood density is modified by rainfall in 32 Australian woody plant species. New Phytol. 185, 493-501. https://doi.org/10.1111/j.1469-8137.2009.03088.x

Padilla, F.M., Pugnaire, F.I., 2007. Rooting depth and soil moisture control Mediterranean woody seedling survival during drought. Funct. Ecol. 21, 489-495. https://doi.org/10.1111/j.1365-2435.2007.01267.x

Pausas, J.G., Pratt, R.B., Keeley, J.E., Jacobsen, A.L., Ramirez, A.R., Vilagrosa, A., Paula, S., Kaneakua-Pia, I.N., Davis, S.D., 2016. Towards understanding resprouting at the global scale. New Phytol. https://doi.org/10.1111/nph.13644 
Pérez-Harguindeguy, N., Diaz, S., Garnier, E., Lavorel, S., Poorter, H., Jaureguiberry, P., BretHarte, M.S.S., Cornwell, W.K.K., Craine, J.M.M., Gurvich, D.E.E., Urcelay, C., Veneklaas, E.J.J., Reich, P.B.B., Poorter, L., Wright, I.J.J., Etc., Ray, P., Etc., Díaz, S., Lavorel, S., Poorter, H., Jaureguiberry, P., Bret-Harte, M.S.S., Cornwell, W.K.K., Craine, J.M.M., Gurvich, D.E.E., Urcelay, C., Veneklaas, E.J.J., Reich, P.B.B., Poorter, L., Wright, I.J.J., Ray, P., Enrico, L., Pausas, J.G., Vos, A.C. de, Buchmann, N., Funes, G., Quétier, F., Hodgson, J.G., Thompson, K., Morgan, H.D., Steege, H. ter, Heijden, M.G.A. van der, Sack, L., Blonder, B., Poschlod, P., Vaieretti, M. V., Conti, G., Staver, A.C., Aquino, S., Cornelissen, J.H.C., 2013. New Handbook for standardized measurment of plant functional traits worldwide. Aust. J. Bot. 61, 167-234.

https://doi.org/http://dx.doi.org/10.1071/BT12225

Pita, P., Gascó, A., Pardos, J.A., 2003. Xylem cavitation, leaf growth and leaf water potential in Eucalyptus globulus clones under well-watered and drought conditions. Funct. Plant Biol. 30, 891-899. https://doi.org/10.1071/FP03055

Pockman, W.T., Sperry, J.S., 2000. Vulnerability to xylem cavitation and the distribution of Sonoran desert vegetation. Am. J. Bot. 87, 1287-1299. https://doi.org/10.2307/2656722

Pockman, W.T., Sperry, J.S., O’leary, J.W., 1995. Sustained and significant negative water pressure in xylem. Nature 378, 715-716. https://doi.org/10.1038/378715a0

Powers, J.S., Vargas G., G., Brodribb, T.J., Schwartz, N.B., Pérez-Aviles, D., Smith-Martin, C.M., Becknell, J.M., Aureli, F., Blanco, R., Calderón-Morales, E., Calvo-Alvarado, J.C., Calvo-Obando, A.J., Chavarría, M.M., Carvajal-Vanegas, D., Jiménez-Rodríguez, C.D., Murillo Chacon, E., Schaffner, C.M., Werden, L.K., Xu, X., Medvigy, D., 2020. A 
catastrophic tropical drought kills hydraulically vulnerable tree species. Glob. Chang. Biol. 26. https://doi.org/10.1111/gcb.15037

Pratt, R.B., Jacobsen, A.L., Golgotiu, K.A., Sperry, J.S., Ewers, F.W., Davis, S.D., 2007. Life history type and water stress tolerance in nine California chaparral species (Rhamnaceae). Ecol. Monogr. 77, 239-253. https://doi.org/10.1890/06-0780

Razgour, O., Forester, B., Taggart, J.B., Bekaert, M., Juste, J., Ibáñez, C., Puechmaille, S.J., Novella-Fernandez, R., Alberdi, A., Manel, S., 2019. Considering adaptive genetic variation in climate change vulnerability assessment reduces species range loss projections. Proc. Natl. Acad. Sci. U. S. A. 116, 10418-10423. https://doi.org/10.1073/pnas.1820663116

RCoreTeam, 2020. R: A language and environment for statistical computing.

Roderick, M.L., Berry, S.L., 2002. Linking wood density with tree growth and environment: a theoretical analysis based on the motion of water. New Phytol. 149, 473-485. https://doi.org/10.1046/j.1469-8137.2001.00054.x

Schreiber, S.G., Hacke, U.G., Chamberland, S., Lowe, C.W., Kamelchuk, D., Bräutigam, K., Campbell, M.M., Thomas, B.R., 2016. Leaf size serves as a proxy for xylem vulnerability to cavitation in plantation trees. Plant Cell Environ. 39, 272-281. https://doi.org/10.1111/pce.12611

Schumann, K., Leuschner, C., Schuldt, B., 2019. Xylem hydraulic safety and efficiency in relation to leaf and wood traits in three temperate Acer species differing in habitat preferences. Trees - Struct. Funct. 33, 1475-1490. https://doi.org/10.1007/s00468-01901874-X 
Searson, M.J., Thomas, D.S., Montagu, K.D., Conroy, J.P., 2004. Wood density and anatomy of water-limited eucalypts. Tree Physiol. 24, 1295-1302. https://doi.org/10.1093/TREEPHYS/24.11.1295

Skelton, R.P., Anderegg, L.D.L., Papper, P., Reich, E., Dawson, T.E., Kling, M., Thompson, S.E., Diaz, J., Ackerly, D.D., 2019. No local adaptation in leaf or stem xylem vulnerability to embolism, but consistent vulnerability segmentation in a North American oak. New Phytol. 223, 1296-1306. https://doi.org/10.1111/nph.15886

Skelton, R.P., Dawson, T.E., Thompson, S.E., Shen, Y., Weitz, A.P., Ackerly, D., 2018. Low vulnerability to xylem embolism in leaves and stems of north american oaks. Plant Physiol. 177, 1066-1077. https://doi.org/10.1104/pp.18.00103

Skelton, R.P., West, A.G., Dawson, T.E., 2015. Predicting plant vulnerability to drought in biodiverse regions using functional traits. Proc. Natl. Acad. Sci. U. S. A. 112. https://doi.org/10.1073/pnas.1503376112

Sperry, J.S., Hacke, U.G., Pittermann, J., 2006. Size and function in conifer tracheids and angiosperm vessels. Am. J. Bot. 93, 1490-1500. https://doi.org/10.3732/ajb.93.10.1490

Sperry, J.S., Meinzer, F.C., McCulloh, K.A., 2008. Safety and efficiency conflicts in hydraulic architecture: Scaling from tissues to trees. Plant, Cell Environ. 31, 632-645. https://doi.org/10.1111/j.1365-3040.2007.01765.x

Trueba, S., Pouteau, R., Lens, F., Feild, T.S., Isnard, S., Olson, M.E., Delzon, S., 2017. Vulnerability to xylem embolism as a major correlate of the environmental distribution of rain forest species on a tropical island. Plant Cell Environ. 40, 277-289. https://doi.org/10.1111/pce.12859 
UNEP, 1997. World atlas of desertification, Second edi. ed. London.

Urban, M.C., 2015. Accelerating extinction risk from climate change. Science 348, 571-3. https://doi.org/10.1126/science.aaa4984

Urli, M., Porté, A.J., Cochard, H., Guengant, Y., Burlett, R., Delzon, S., 2013. Xylem embolism threshold for catastrophic hydraulic failure in angiosperm trees. Tree Physiol. 33, 672-683. https://doi.org/10.1093/treephys/tpt030

Vilagrosa, A., Hernández, E.I., Luis, V.C., Cochard, H., Pausas, J.G., 2014. Physiological differences explain the co-existence of different regeneration strategies in Mediterranean ecosystems. New Phytol. 201, 1277-1288. https://doi.org/10.1111/nph.12584

Villagra, M., Campanello, P.I., Bucci, S.J., Goldstein, G., 2013. Functional relationships between leaf hydraulics and leaf economic traits in response to nutrient addition in subtropical tree species. Tree Physiol. 33, 1308-1318. https://doi.org/10.1093/treephys/tpt098

Weston, P.H., 1995. Proteaceae, Flora of Australia. Australian Biological Resources Study/CSIRO Publishing.

Wheeler, E.A., Baas, P., Rodgers, S., 2007. Variations in dicot wood anatomy: A global analysis based on the insidewood database. IAWA J. 28, 229-258. https://doi.org/10.1163/22941932-90001638

Wimmer, R., Downes, G.M., Evans, R., Rasmussen, G., French, J., 2002. Direct effects of wood characteristics on pulp and handsheet properties of Eucalyptus globulus. Holzforschung 56, 244-252. https://doi.org/10.1515/HF.2002.040

Wright, I.J., Dong, N., Maire, V., Prentice, I.C., Westoby, M., Díaz, S., Gallagher, R. V., Jacobs, 
B.F., Kooyman, R., Law, E.A., Leishman, M.R., Niinemets, Ü., Reich, P.B., Sack, L., Villar, R., Wang, H., Wilf, P., 2017. Global climatic drivers of leaf size. Science (80-. ). 357, 917-921. https://doi.org/10.1126/science.aal4760

Zeppel, M.J.B., Harrison, S.P., Adams, H.D., Kelley, D.I., Li, G., Tissue, D.T., Dawson, T.E., Fensham, R., Medlyn, B.E., Palmer, A., West, A.G., McDowell, N.G., 2015. Drought and resprouting plants. New Phytol. 206, 583-589. https://doi.org/10.1111/nph.13205

Zhang, S.-B., Zhang, J.-L., Cao, K.-F., 2017. Divergent hydraulic safety strategies in three Cooccurring anacardiaceae tree species in a Chinese savanna. Front. Plant Sci. 7. https://doi.org/10.3389/fpls.2016.02075 


\section{Supporting information}

Fig S4: Relationship between drought tolerance $\left(\mathrm{P}_{50}\right)$ and functional traits for Hakea species showing different biome, life-history and leaf form.

Fig S5: Hydraulic vulnerability curves for Hakea species showing the percentage loss of conductance against the stem water potential measured from the Cavitron. 